\title{
Statistical Analysis on the Relationship Between Exports and Economic Growth in Sierra Leone (1990-2019)
}

\author{
Matthew James Turay ${ }^{1, ~ *, ~ I s a a c ~ T a m b a ~ I s s a ~}{ }^{2}$, Ishmail Sheriff ${ }^{3}$, Abdulai Koedoyoma ${ }^{4}$, \\ Ibrahim Kuyateh ${ }^{4}$ \\ ${ }^{1}$ School of Mathematics and Statistics, Beijing Technology and Business University, Beijing, China \\ ${ }^{2}$ School of Technology, Njala University, Njala, Sierra Leone \\ ${ }^{3}$ School of Environmental Science \& Engineering, Suzhou University of Science and Technology, Suzhou, China \\ ${ }^{4}$ Business School, Beijing Technology and Business University, Beijing, China
}

\section{Email address:}

matthewjamesturay@yahoo.com (M. J. Turay), isaactambaissa@gmail.com (I. T. Issa), s.ishmail@rocketmail.com (I. Sheriff), koedoyomaabdulai@yahoo.com (A. Koedoyoma), ib.kuyateh1990@gmail.com (I. Kuyateh)

${ }^{*}$ Corresponding author

\section{To cite this article:}

Matthew James Turay, Isaac Tamba Issa, Ishmail Sheriff, Abdulai Koedoyoma, Ibrahim Kuyateh. Statistical Analysis on the Relationship Between Exports and Economic Growth in Sierra Leone (1990-2019). Journal of Business and Economic Development. Vol. 6, No. 3, 2021, pp. 148-154. doi: 10.11648/j.jbed.20210603.13

Received: February 29, 2021; Accepted: February 18, 2021; Published: July 13, 2021

\begin{abstract}
In order to boost up the economic growth of any country, Exports should be considered as key factor as it contributes immensely in which Sierra Leone as a nation is no exception. Therefore, this research paper target to investigate the effect of export on the economic growth of Sierra Leone using time series data of exports and the gross domestic products ranging from 1990- 2019 which was source from the World Bank Indicators. In order to accomplish the aim of this paper, descriptive statistics, regression, correlation, Augmented Dickey- Fuller Unit root test, Johansen cointegration test, Vector Auto regression model, diagnostic test and the Pair- wise Granger causality test were the tools used to analyze the data. Based on the results from both regression analysis, it can be seen that export has a significant positive effect on the economic growth of Sierra Leone. Augmented Dickey-Fuller unit root test results shows existence of stationarity at first difference was detected, while the cointegration test results revealed that, there is no relationship between the exports and economic growth. However, the Vector Auto regressive model test revealed that, exports have a significant effect on the economic growth as well. Granger causality test, shows that both exports influence the Gross Domestic Product of Sierra leone.
\end{abstract}

Keywords: Export, Economy, Sierra Leone, Relationship, Cointegration

\section{Introduction}

Sierra Leone is a small country located in West Africa and is bordered by Liberia, Guinea and the Atlantic Ocean respectively. It has been proven over the years that; exports have played a very vital role towards the economy growth of the country. According to the Observation Economic Complexity (OEC, 2019), the country is ranked 152nd largest exporting economy in the world. Iron ore, diamonds, titanium ore, cocoa and coffee, aluminum ore, and timber (OEC, 2019) are among the country's major exporting commodities [19]. For instance, in 2017 the country's gross export was $\$ 839$ million while the imported cost was $\$ 1.3$ billion causing a negative balance of trade of $\$ 457 \mathrm{~m}$.

It is clear that exports have been the engine in upgrading the production quality, motivating foreign investments, supply of foreign currencies to the state treasury and creating a healthy economy environment for competition and productivity. Exports also help influencing the expenditure balance, reduction of unemployment rate.

According to the Sierra Leone Investment and Export Promotion Agency (SLIEPA), in 2011 about 51 percent growth of the gross domestic product was been contributed by the agricultural in which 17 percent derived from exporting of commodities [20]. Over the past years, the country has firmly depended on the agriculture sector by 
exporting significant quantities of agricultural commodities which includes coffee, cocoa and oil palm.

Over the years, the country produced various natural resources which includes bauxite, rutile, iron ore and gold in which iron-ore has contributes towards the gross domestic products of the country. Notwithstanding, the closure of iron means has resulted increase in the production of other minerals like diamond, bauxite and gold. The contribution of this mineral resources has greatly influenced the gross domestic products, although the country has experienced a decline which as well decrease the economic performance. [21]

In order to accomplish this this study, the paper is been structured into sections: section one present the introduction of the study, section two deals with various literature related to the topic, section three discuss the data and methodology used, section four present the analysis and interpretation of the data while section five discuss the conclusion and recommendations of this study.

\section{Literature Review}

Different studies have been conducted by researchers, scholars on exports and the economic growth using time series in which literature from Sierra Leone is limited on the topic and other related articles. Matthee and Naude (2007), investigate the effect of exports diversification on the region growth in which their findings show that diversifying the manufactured products has proven to be important especially developing countries like in Sierra Leone as it is vital in introducing new innovation, technology and knowledge [1]. It also proven that decrease in export concentration which results as well to direct trade terms which will be vital in developing the economic growth [2].

Export and trade over the years has serve as a pivotal role in the development of the economy and further help in the poverty reduction [3-4] especially in developing nations like Sierra Leone. Increasing in the various level of diverse export could aid in expand the economy as a whole [5]). In addition, similar conclusion was also been point out in line export diversification and the growth of the economy [6-7].

It can also be seen as a vital stimulus in development and the sustainability of the economic growth of nation [8] and a major indicator for economic welfare world at large. The relationship between export and import has been a hotly contested topic over the past decades as nation's economic and industrial strength expanded [9]. Various plethora's of social and scientific research has been carried out to unearth the relationship between export and import and their role in economic development [9]. In developing countries, export and import play a critical role in ensuring the economic sustainability of countries as well as their trade balance [10]. The increase in export of any nation has significant impacts on the economic performance of that nation in terms of its technological advancement and other sectors [11]. Khan et al. (2012), investigated the nexus between import, export, and economic growth [12]. Mulok et al., (2011) investigated the import and economic growth in Malaysia from 1970-2007 periods [13].
According to Utonga and Dimoso, (2019), there is both positive and negative relationship between export and import commodity [8]. Scholarly economist has tied economic growth to export potential simply because income earned from exports serve as foreign reserve for countries [8]. An increase in the export ability of a nation can influence the production and employment sector and at the same time relax balance payment [11]. Recent scientific evidence has shown that exporting is a catalyst for the economic growth and development.

In recent years, a plethora's of studies from scholarly economic policy and decision makers has examined the relationship between import and export. Aka, (2006) prone to the relationship between openness and globalization on economic development in Cote d'Ivoire using time series data ranging from 1960 to 2005 [14]. In addition, Taghavi et al, (2012), investigated exports and imports impact on the development of Iran economy considering time series data ranging from 1962-2011 [15]. Bakari and Krit (2017) using Mauritania as case study studied the export-import nexus and its economic growth impact [16]. Mehta, (2015) examined the relationship between import and export and their subsequent economic growth impact on India from 1976-2014 [17]. Akbay (2011), explored the impacts of international trade on the Turkish economy from 1998-2010 [18].

To the best of my knowledge, literature on the export and economic growth relationship of Sierra Leone is scarce if not unable altogether. Therefore, the purpose of this studies is to examine the relationship that exist between exports and the economic growth in Sierra Leone using the exports and the Gross Domestic Product data from 1990 to 2019.

\section{Data, Methodology and Model Specification}

\subsection{Methods}

This research paper used annual time series ranging from 1990 to 2019 which will be help to investigate the effects of exports on the economic growth of the country and also to arrive at appropriate decision and conclusion. Basic descriptive statistics will be used in order to describe the variables. Furthermore, the estimation techniques will include the unit root test which will be used to test for stationarity of the variables. Jonhansen cointegration test can use to determine if there is a cointegration between the variables. If the cointegration test shows that there is presence of a cointegration relation between the variables studied, then model VECM will be used and while Vector Autoregressive test can be used if there is an absence of cointegration relation between the variables from the cointegration test.

\subsection{Data Source}

This paper will focus on the annual time series data of Exports (US \$) and Gross domestic product (base year 2010) ranging from 1990 to 2019. All data set are taken from World Bank Indicators. For econometric estimation the natural 
logarithms of the variables will be used in the analysis since they are measured in billions of US dollars.
The trend of the Gross domestic product and the exports from 1990 to 2019 of Sierra Leone is shown in the graph below.

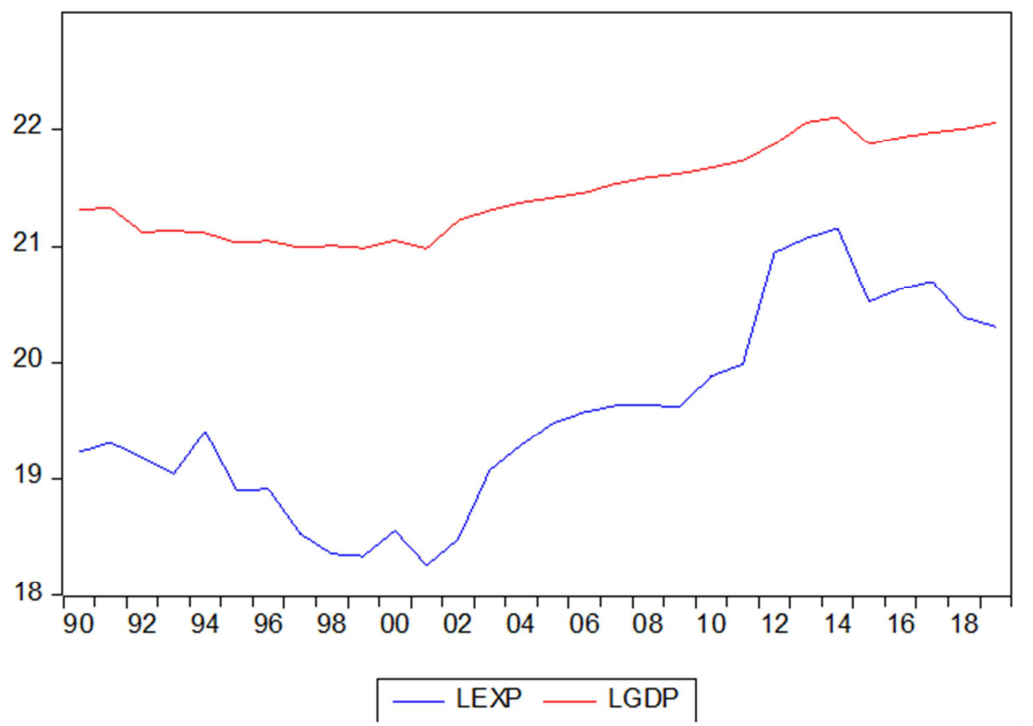

Figure 1. Export and Gross domestic product (1990-2019).

\subsection{Research Model Specification}

In order to have a proper understanding on the relationship that exist between Economic growth and the Export rate of the country, the study establish an economic model in which the Gross domestic products will be used as the dependent variable, while the Exports of goods and services will be used as the independent variable. Thus, the model function is expressed as stated below:

$$
G D P_{t}=f(E X P)
$$

The function above can also be represented as in a loglinear econometric format thus:

$$
\log (G D P)_{t}=\alpha_{0}+\alpha_{1} \log (E X P)_{t}+\mu_{t}
$$

Where, $\alpha_{0}=$ constant term, $\alpha_{1}=$ coefficient of variable (exports) and $\mu_{t}=$ random error term, assumed to be normally, identically and independently distributed.

\section{Empirical Analysis}

Table 1. Descriptive Summary of the Variables.

\begin{tabular}{lll}
\hline & EXP & GDP \\
\hline Mean & 19.54921 & 21.46337 \\
Median & 19.44781 & 21.39334 \\
Maximum & 21.15505 & 22.10570 \\
Minimum & 18.26393 & 20.98395 \\
Std. Dev. & 0.854840 & 0.385869 \\
Skewness & 0.314745 & 0.289956 \\
Kurtosis & 2.086631 & 1.670558 \\
Jarque-Bera & 1.538126 & 2.629641 \\
Probability & 0.463447 & 0.268522 \\
Sum & 586.4763 & 643.9011 \\
Observations & 30 & 30 \\
\hline
\end{tabular}

Table 1 above presents the results of the descriptive statistics of the variables in which the GDP represent the dependent variable and while exports (EXP) is the independent variable. The mean, median, standard deviation, sample variance, minimum and maximum values were recorded. This was analyzed in order to give an overall description of the data used in the model with thirty (30) observations for all the variables used in this research paper.

The results (table 1) that all the maximum values for all the variable close to the mean and the median indicating that there is not much problem with the outliers. Among the variables above, the Gross domestic products (GDP) recorded the highest average (21.46337) and with a standard deviation of 0.385869 , while the exports (EXP), the lowest average (19.54921) with a standard deviation of 0.854840 . This implies that both the two variables have greater effects to each in order to increase the economic growth of the country.

The standard deviation values show the average distance from the mean values of the variables; therefore, it can be seen that there is much deviation of the values from the average mean.

\subsection{Correlation and Regression Analysis}

Table 2. Correlation output.

\begin{tabular}{lll}
\hline & GDP & EXP \\
\hline GDP & 1 & \\
EXP & 0.949817 & 1 \\
\hline
\end{tabular}

Table 2 shows the relationship between the dependent and independent variables. Base on the outcome (table 2), there is a direct strong relationship between the exports and the Gross domestic product per capita (0.949817). Furthermore, it can be clearly seen that there is a direct strong relationship 
between the dependent variable (GDP) and the independent variable (EXP).

Table 3. Regression Analysis.

\begin{tabular}{|c|c|c|c|c|}
\hline Variable & Coefficient & Std. Error & t-Statistic & Prob. \\
\hline $\mathrm{C}$ & 13.0818 & 0.522132 & 25.05460 & 0.0000 \\
\hline LEXP & 0.4287 & 0.026684 & 16.06737 & 0.0000 \\
\hline R-squared & 0.902153 & Mean dependent var & & 21.46337 \\
\hline Adjusted R-squared & 0.898658 & S. D. dependent var & & 0.385869 \\
\hline S. E. of regression & 0.122838 & Akaike info criterion & & -1.291553 \\
\hline Sum squared resid & 0.422500 & Schwarz criterion & & -1.198139 \\
\hline Log likelihood & 21.37329 & Hannan-Quinn criter. & & -1.261669 \\
\hline F-statistic & 258.1604 & Durbin-Watson stat & & 0.689303 \\
\hline Prob (F-statistic) & 0.000000 & & & \\
\hline
\end{tabular}

Thus, the equation function is illustrated as stated below:

$$
L G D P=13.0818+0.4287 L E X P
$$

From table and equation (3) above, it can be deduced that export (EXP) has a direct relationship with Gross domestic products (GDP). The results further revealed that a unit increase in the country's exports will lead to an increase in the gross domestic products by approximately 0.4287 (4.287\%). However, this clearly shows when a country's exports improve, then it will greatly improve the economic growth. The p-value $(0.0000)$ is less than the level of significance $(\alpha=0.005)$ of this study, thus the results signify that export is statistically significant towards the dependent variable (GDP).

The R-squared value for this model is 0.9021 and this implies that the independent variable (EXP) account for about $90.21 \%$ of variations in the Gross domestic Rate (GDP). The p-value of F-statistics (0.0000000) indicate that the entire model is statistically significant at both $1 \%$ and $5 \%$ level.

\subsection{Unit Root Test}

The Augmented Dickey-Fuller (ADF) unit root test was used to test the stationarity of the variables and results are given in Table 1 below. The results in Table-1 show that all the variables were not stationary in level form and for different level (1\%, 5\% and 10\%). However, after ADF first difference test with constant in all levels $(1 \%, 5 \%$ and $10 \%)$ the variables become stationary.

Table 4. Augmented Dickey- Fuller Unit root test.

\begin{tabular}{|c|c|c|c|c|c|}
\hline \multirow{2}{*}{ Variable } & \multicolumn{3}{|c|}{ ADF Level with constant only } & \multicolumn{2}{|c|}{ ADF First difference with constant only } \\
\hline & Test critical values & t. statistic & Prob.* & t. statistic & Prob.* \\
\hline L (GDP) $1 \%$ level & -3.679322 & 0.244048 & 0.9708 & -4.685362 & 0.0009 \\
\hline L (GDP) $5 \%$ level & -2.967767 & & & & \\
\hline L (GDP) $10 \%$ level & -2.622989 & & & & \\
\hline L (EXP) $1 \%$ level & -3.679322 & -0.787824 & 0.8077 & -4.896394 & 0.0005 \\
\hline L (EXP) $5 \%$ level & -2.967767 & & & & \\
\hline L (EXP) $10 \%$ level & -2.622989 & & & & \\
\hline
\end{tabular}

Table 5. Lag Order Selection Criteria.

\begin{tabular}{lllllll}
\hline Lag & LogL & LR & FPE & AIC & SC & HQ \\
\hline 0 & -35.57686 & NA & 0.002401 & 1.847075 & 2.036796 & 1.986562 \\
1 & 56.14833 & 26.5909 & $2.50 \mathrm{e}-04^{*}$ & $-2.053293 *$ & $-1.807208^{*}$ & $-1.871307^{*}$ \\
2 & 88.28850 & 3.683168 & $3.04 \mathrm{e}-05$ & -1.891948 & -1.088899 & -1.586142 \\
3 & 78.92343 & $16.99956^{*}$ & $2.88 \mathrm{e}-05$ & -1.956937 & -0.809723 & -1.520072 \\
4 & 80.80610 & 2.786348 & $3.91 \mathrm{e}-05$ & -1.672244 & -0.180866 & -1.104319 \\
\hline
\end{tabular}

*indicates lag order selected by the criterion, LR: sequence modified LR test statistic (each test at 5\% level), FPE: Final prediction error, AIC: Akaike information criterion, SC: Schwarz information criterion, HQ: Hannan-Quinn information criterion.

Table 6. Result of the Co-integration Test based on Johansen method.

\begin{tabular}{lllll}
\hline Unrestricted Cointegration Rank Test (Trace) & & & \\
\hline Hypothesized No. of CE (s) & Eigenvalue & Trace Statistic & 0.05 Critical Value & Prob.** \\
\hline None & 0.191540 & 6.377121 & 15.49471 & 0.6509 \\
At most 1 & 0.015016 & 0.423638 & 3.841466 & 0.5151 \\
\hline \multicolumn{5}{l}{} \\
\hline Unrestricted Cointegration Rank Test (Maximum Eigenvalue) & Max-Eigen Statistic & $\mathbf{0 . 0 5}$ Critical Value & Prob.** $^{* *}$ \\
\hline Hypothesized No. of CE (s) & Eigenvalue & 5.953483 & 14.26460 & 0.6192 \\
\hline None & 0.191540 & 0.423638 & 3.841466 & 0.5151 \\
At most 1 & 0.015016 & & \\
\hline
\end{tabular}

Table 5 which revealed the FPE, AIC, SC and HQ statistics are chosen lag 1 for each endogenous variable in their 
autoregressive and distributed lag structures in the estimable Vector Auto-Regression model and therefore, lag of one (1) is used for estimation purpose.

In table 3, the results of the Johansen cointegration test indicate that there is no relationship of cointegration between exports, imports and GDP which mean that we have to apply the Vector Auto-Regression estimation.

$$
\mathrm{LGDP}=\mathrm{C}(6) * \operatorname{LEXP}(-1)+\mathrm{C}(7) * \operatorname{LEXP}(-2)+\mathrm{C}(8) * \operatorname{LGDP}(-1)+\mathrm{C}(9) * \operatorname{LGDP}(-2)+\mathrm{C}(10)
$$

Table 7. Vector Auto Regression Analysis.

\begin{tabular}{llll}
\hline & Coefficient & Std. Error & t-Statistic \\
\hline C (6) & 0.066364 & 0.088704 & 0.748151 \\
C (7) & 0.100016 & 0.093001 & 1.075439 \\
C (8) & 1.099432 & 0.260202 & 4.225305 \\
C (9) & 0.280869 & 0.322697 & 0.870382 \\
C (10) & -4.877505 & 2.803635 & -1.739708 \\
R-squared & 0.948921 & Mean dependent var & 0.0233 \\
Adjusted R-squared & 0.940037 & S. D. dependent var & 0.0093 \\
S. E. of regression & 0.097417 & Akaike info criterion & 0.0953 \\
Sum squared resid & 0.218271 & Schwarz criterion & 21.47367 \\
Log likelihood & 28.22883 & Hannan-Quinn criter. & 0.397826 \\
F-statistic & 106.8196 & Durbin-Watson stat & -1.659202 \\
Prob (F-statistic) & 0.000000 & & -1.421308 \\
\hline
\end{tabular}

Table 8. Wald Test Results.

\begin{tabular}{llll}
\hline Test Statistic & Value & df & Probability \\
\hline F-statistic & 29.04936 & $(2,23)$ & 0.0000 \\
Chi-square & 58.09873 & 2 & 0.0000 \\
Null Hypothesis: C $(8)=\mathrm{C}(9)=0$ & & & \\
Null Hypothesis Summary: & & Value & Std. Err. \\
Normalized Restriction (=0) & & 1.099432 & 0.260202 \\
C $(8)$ & & 0.280869 & 0.322697 \\
C (9) & & & Probability \\
\hline & Value & df & 0.0028 \\
\hline Test Statistic & 1.711360 & $(2,23)$ & 0.0106 \\
\hline F-statistic & 3.422720 & 2 & Std. Err. \\
Chi-square & & & 0.088704 \\
Null Hypothesis: C $(6)=C(7)=0$ & & & 0.093001 \\
Null Hypothesis Summary: & & Value & \\
Normalized Restriction $(=0)$ & & 0.066364 & \\
C (6) & & 0.100016 & \\
C (7) & & & \\
\hline
\end{tabular}

Base on the results (table 7), Gross domestic product itself both the lag period has a positive influence on current period. The absolute value of the coefficient of the first period has a greater influence on GDP at current period than that of the second order lag. Based on Wald test, both lags can jointly influence itself since their p-values are less than 5\%. Export is positively related to Gross domestic product. In the first lagged period, export has a positive influence on Gross domestic product at current period. In the two lagged period export has a positive influence on Gross domestic product at current period but greater than the former.

Therefore, in the short the rising exports can increase the Gross domestic products. Based on the Wald test both the lags can jointly influence Gross domestic products. The Rsquared value (0.948) which signified that about 94.8 percent of the variation in the lag of the Gross domestic products can be accounted by the lag of the exports. The Durbin Watson results (1.954) shows that there is no serial correlation.

Table 9. Pair-wise Granger Causality Tests.

\begin{tabular}{ll}
\hline Null Hypothesis: & Prob. \\
\hline LGDP does not Granger Cause LEXP & 0.0506 \\
LEXP does not Granger Cause LGDP & 0.2028 \\
\hline
\end{tabular}

From table 9 above, the pair-wise Granger causality test shows that we reject the null hypothesis since the probability values are all greater than $5 \%$, thus accept the alternative hypothesis (both variables do granger cause to each other). The results further revealed that there is a presence of causal relationship between exports and the gross domestic products.

\subsection{Diagnostic Test}

In order to test the fitness of the model, this research applied Langrage multiplier is used to test for serial correlation, followed by the white test for heteroskedasticity and then finally the Jaque- Bera for normality test. 
Table 10. Diagnostic test results.

\begin{tabular}{llll}
\hline Test & Null hypothesis & t-statistic & Probability \\
\hline Langrage Multiplier (LM) & No serial correlation & 8.243 & 0.613 \\
Jarque-Bera & There is a normal distribution & 1.538 & 2.629 \\
White (CH-sq) & No conditional heteroskedasticity & 566.070 & 0.268 \\
\hline
\end{tabular}

Table 10 above shows that, the serial correlation recorded t-statistic of 8.243 with a probability value of 0.613 . Thus, the null hypothesis is accepted and conclude that there is no serial correlation. The results further shows that there is normal distribution and no conditional heteroskedasticity since their $\mathrm{p}$-values are greater than the level of significance $(\alpha=0.05)$.

\section{Conclusion and Recommendations}

The main focus of this study is to determine the link between exports and economic growth of Sierra Leone in the period 1990-2019. The Cointegration test, Vector AutoRegressive model and Pair-wise Granger causality tests are applied in order to investigate the relationship between exports and Gross Domestic Product. The result from the regression and correlation reveals that there is a relationship between the Gross domestic product and the exports. Stationarity tests shows that all the variables where stationary in the first difference.

The cointegration test results show that there is absence of cointegration relationship, and therefore Vector Autoregression (VAR) model can be applied. The results of the Vector Auto regression model shows that exports have positive effect on the economic growth of the country. The Pair-wise Granger Causality Tests results indicate that exports and imports do not cause economic growth. Findings have shown that export is vital as it serves as a source of economic growth in Sierra Leone.

Based on the results from the empirical analysis, good policies of trade and foreign exchange which will stimulate the growth of exports should be embarked on by the government since exports plays a significant role towards the economic growth and also increase the employment rate of the country. Government also encourages the imports of essential raw materials and other commodities as it will help to boost the economic growth of the country.

Based on the findings of the research, it advisable for the government and policy makers to continue to improving on the exports as it helps greatly to the development of the economy of the nation and also help to create employment. In addition, Sierra Leone government should also consider trade openness as it served as pillar of economic growth. Potential exporters should also be encouraged by government and policy.

\section{References}

[1] Matthee, M., \& Naude, W. (2007) Export diversity and regional growth empiricalevidence from South Africa.
[2] Petersson, L. (2005). Export diversification and intra-industry trade in South Africa. South African journal of economics, 73, 785-802.

[3] Bakari, S and Mabrouki, M. (2017). The nexus between exports, imports, Domestic investment and Economic growth in Japan. Economic Policy, (2116), 0-33. https://doi.org/10.1227/01.NEU.0000349921.14519.2A.

[4] Dutt, S. D., Ghosh, D., \& Austin, A. (2015). Export Growth---economic Growth Nexus: An Empirical Re-examination. Journal of Business and Economics JBE, 6 (12), 1999-2007.

[5] Herzer, D., \& Nowak-Lehnmann, D. F., (2006). What does export diversification do for growth? An econometric analysis.

[6] Agosin, M, R. (2007). Export diversification and growth in emerging countries. Available: http://www.econ.uchile.cl/uploads/publicacion/7fec2632b4c3-45a3-ab78-0970614f5bab.pdf (March 18, 2012).

[7] Ferreira, G. F. (2009). The expansion and diversification of the export sector and economic growth: The Costa Rican experience.

[8] Utonga and Dimoso, 2019, The Nexus Between Export and Economic Growth in Tanzania. Journal of Business School, vol. 2, issue. 6, pp. 49-59.

[9] Vardari, M. L. (2015). Relationship between Import-Exports and Economic Growth: The Kosova Case Study. SSRN Electronic Journal, https://doi.org/10.2139/ssrn.288973.

(March).

[10] Bakari, S., \& Mabrouki, M. (2017). Impact of Exports and Imports on Economic Growth: New Evidence From Panama. Journal of Smart Economic Growth, 2 (1), 67-79.

[11] Amiri, A., \& Gerdtham, U. (2011). Relationship between exports, imports, and economic growth in France: evidence from cointegration analysis and Granger causality with using geostatistical models. MPRA Paper No. 34190. Retrieved from http://mpra.ub.uni-muenchen.de/34190/.

[12] Khan, D. (2012). Exports, imports and economic growth nexus: Time series evidence from Pakistan. World Applied Sciences Journal, 18 (4), 538-542.

[13] Mori Kogid, Dullah Mulok, Kok Sook Ching, Jaratin Lily (2011). Does Import Affect Economic Growth in Malaysia. The Empirical Economics Letters, 10 (3): (March 2011).

[14] Aka, B. F., 2006. "Openness, Globalization and Economic Growth: Empirical Evidence from Cote d'Ivoire, 1969-2002," International Journal of Applied Econometrics and Quantitative Studies, Euro-American Association of Economic Development, vol. 3 (2), pages 67-86.

[15] Taghavi, M., Goudarzi, M., Masoudi, E., \& Gashti, H. P. (2012). Study on the Impact of Export and Import on Economic Growth in Iran, 2 (12), 12787-12794. 
[16] Bakari, S. and Krit, M. (2017). The Nexus between Exports, Imports and Economic Growth: Evidence from Mauritania. International Journal of Economics and Empirical Research. 5 (1), 10-17.

[17] Sachin N. Mehta (2015). The Dynamics of Relationship between Exports, Import and Economic Growth in India. International Journal of Research in Humanities \& Soc. Sciences, Vol. 3, Issue: 7 July, 2015.
[18] Akbay O. S (2011). Trade-Growth Nexus: Turkish Case. Euro Economic. Issue $2(28) / 2011$.

[19] Observatory Economic Complexity, 2019.

[20] Sierra Leone Investment and Export Promotion Agency (SLIEPA).

[21] Sierra Leone Extractive Industries Transparency Initiative (SLEITI). 